\title{
Duration of Protection Against SARS-CoV-2 Reinfection and Associated Risk of Reinfection Assessed with Real-World Data
} \author{
$\mathrm{MD}^{4}$; Lynne Penberthy, $\mathrm{MD}^{4}$ \\ ${ }^{1}$ Aetion, Inc., New York, New York \\ ${ }^{2}$ Quest Diagnostics, Secaucus, New Jersey \\ ${ }^{3}$ Labcorp Drug Development, Burlington, North Carolina \\ ${ }^{4}$ National Cancer Institute, Bethesda, Maryland \\ ${ }^{5}$ HealthVerity, Philadelphia, PA
}

Shannon L. Reynolds, MSPH ${ }^{1}$; Harvey W. Kaufman, $\mathrm{MD}^{2}$; William A. Meyer III, $\mathrm{PhD}^{2}$; Chris Bush, $\mathrm{MPH}^{1}$; Oren Cohen, $\mathrm{MD}^{3}$; Kathy Cronin, $\mathrm{PhD}^{4}$; Carly Kabelac, BS ${ }^{1}$; Sandy Leonard, $\mathrm{MPH}^{5 ;}$ Steve Anderson, $\mathrm{PhD}^{3}$; Valentina Petkov, MD ${ }^{4}$; Douglas Lowy, MD ${ }^{4}$; Norman Sharpless,

Corresponding author:

Shannon L. Reynolds

5 Penn Plaza, $7^{\text {th }}$ Floor

New York, NY 10001

Shannon.reynolds@aetion.com

Manuscript Word Count: 2,997 


\section{Key Points}

\section{Question:}

How long does prior SARS-CoV-2 infection provide protection against SARS-CoV-2 reinfection?

\section{Finding:}

Among >22 million individuals tested February 2020 through April 2021, the relative risk of reinfection among those with prior infection was $87 \%$ lower than the risk of infection among individuals without prior infection. This protection was durable for up to a year. Factors associated with increased likelihood of reinfection included older age (85+ years), comorbid immunologic conditions, and living in congregate care settings; healthcare workers had lower risk.

\section{Meaning:}

Prior SARS-CoV-2 infection provides a durable, high relative degree of protection against reinfection. 


\begin{abstract}
Importance:

Better understanding of the protective duration of prior SARS-CoV-2 infection against reinfection is needed.
\end{abstract}

\title{
Objective:
}

Primary: To assess the durability of immunity to SARS-CoV-2 reinfection among initially unvaccinated individuals with previous SARS-CoV-2 infection. Secondary: Evaluate the crude SARS-CoV-2 reinfection rate and associated characteristics.

\section{Design and Setting:}

Retrospective observational study of HealthVerity data among 144,678,382 individuals, during the pandemic era through April 2021.

\section{Participants:}

Individuals studied had SARS-CoV-2 molecular diagnostic or antibody index test results from February 29 through December 9, 2020, with $\geq 365$ days of pre-index continuous closed medical enrollment, claims, or electronic health record activity.

\section{Main Outcome(s) and Measure(s):}

Rates of reinfection among index-positive individuals were compared to rates of infection among index-negative individuals. Factors associated with reinfection were evaluated using 
multivariable logistic regression. For both objectives, the outcome was a subsequent positive molecular diagnostic test result.

\section{Results:}

Among 22,786,982 individuals with index SARS-CoV-2 laboratory test data $(2,023,341$ index positive), the crude rate of reinfection during follow-up was significantly lower $(9.89 / 1,000$ person years) than that of primary infection (78.39/1,000 person years). Consistent with prior findings, the risk of reinfection among index-positive individuals was $87 \%$ lower than the risk of infection among index-negative individuals (hazard ratio, $0.13 ; 95 \% \mathrm{CI}, 0.13,0.13$ ). The cumulative incidence of reinfection among index-positive individuals and infection among index-negative individuals was $0.85 \%$ (95\% CI: $0.82 \%, 0.88 \%)$ and $6.2 \%(95 \% \mathrm{CI}: 6.1 \%, 6.3 \%)$, respectively, over follow-up of 375 days. The duration of protection against reinfection was stable over the median 5 months and up to 1-year follow-up interval. Factors associated with an increased reinfection risk included older age, comorbid immunologic conditions, and living in congregate care settings; healthcare workers had a decreased reinfection risk.

\section{Conclusions and Relevance:}

This large US population-based study demonstrates that SARS-CoV-2 reinfection is uncommon among individuals with laboratory evidence of a previous infection. Protection from SARS-CoV2 reinfection is stable up to one year. Reinfection risk was primarily associated with age $85+$ years, comorbid immunologic conditions and living in congregate care settings; healthcare workers demonstrated a decreased reinfection risk. These findings suggest that infection induced immunity is durable for variants circulating prior to Delta. 


\section{Rationale and Background}

To date, over 329 million confirmed cases of COVID-19 have been diagnosed globally. ${ }^{1}$ Survivors have a risk of reinfection that can be associated with serious clinical outcomes. ${ }^{2,3}$ Our previous study of a national U.S. cohort found that seropositivity was associated with reduced risk of subsequent infection over a relatively short interval. ${ }^{4}$ That study demonstrated that at $>90$ days after an index SARS-CoV-2 antibody test, the ratio of positive nucleic acid amplification test (NAAT) results between those who were index SARS-CoV-2 positive versus index negative individuals was 0.1 , suggesting prior infection provided $\sim 90 \%$ protection from reinfection. Similar results were observed using real-world data (RWD) and different study designs. ${ }^{5-9}$ Research has also demonstrated that serum SARS-CoV-2 neutralizing antibodies and T cell immunity correlate with protection against infection and reinfection. ${ }^{10,11}$

Previous short-term studies relying on RWD indicate prior SARS-CoV-2 infection may offer protection for at least 7 months. ${ }^{5-9}$ Existing studies of reinfection have limited follow-up time for observing reinfection and often limited study population size and geography. For instance, many are limited to healthcare workers or students and lack generalizability to other atrisk populations, such as the elderly and individuals with comorbidities. ${ }^{5-9}$ Accordingly, it is unclear whether the duration of protection associated with SARS-CoV-2 seropositivity may be substantially longer, and the impact of patient-level characteristics on the risk of reinfection is also unknown.

Large-scale RWD offer an opportunity to study patterns of infection and reinfection, available longitudinally at the individual level, making it possible to study the experiences of a seropositive population with COVID-19 in near-real time. Further advantages of real-world database studies include maximizing sample size, the ability to evaluate risk within subgroups 
and specific patient characteristics, and greater data capture of the patient experience over time. The primary objective of this study was to estimate the duration of protection provided against laboratory confirmed SARS-CoV-2 reinfection among index SARS-CoV-2 positive individuals compared to the risk of infection among index SARS-CoV-2 negative individuals. The secondary objective was to estimate the rate of reinfection among those previously identified as SARS-CoV-2 positive and evaluate demographic and comorbid characteristics associated with the risk of SARS-CoV-2 reinfection.

\section{Methods}

\section{Data sources}

The study population began with 144,678,382 individuals derived from US RWD sources curated by HealthVerity and with records of medical services obtained from February 29, 2020, through April 30, 2021. This dataset aggregates multiple unique record sources across commercial laboratory databases (including an estimated $60 \%$ of aggregate SARS-CoV-2 testing performed in the US), medical claims (both open and closed claims), pharmacy databases (both claims and retail), hospital chargemaster (CDM) and outpatient electronic health records (EHR). Patient records, using a unique, interoperable, de-identified token, are linked across laboratory test results, medical and pharmacy claims, CDM, and any available EHR. The data included in this study are compliant with HIPAA such that no patient can be reidentified. The study was deemed exempt by the New England Institutional Review Board (\#1-9757-1).

\section{Study Design}

\section{Study Population}


medRxiv preprint doi: https://doi.org/10.1101/2022.02.25.22271515; this version posted February 26, 2022. The copyright holder for this preprint (which was not certified by peer review) is the author/funder, who has granted medRxiv a license to display the preprint in perpetuity.

All rights reserved. No reuse allowed without permission.

The dataset included records for individuals with an index NAAT or SARS-CoV-2 antibody test from February 29, 2020 (when SARS-CoV-2 NAAT first became available for molecular diagnostic testing), through December 9, 2020 (prior to COVID-19 vaccine introduction). Individuals included based on an antibody test result could enter starting on April 15, 2020, the earliest availability of an antibody test with US Food and Drug Administration (FDA) Emergency Use Authorization (EUA).

For the primary study objective, a cohort of SARS-CoV-2-tested individuals was identified. Individuals entered based on their first SARS-CoV-2 antibody or NAAT test result (index date). Individuals were required to have $\geq 12$ months of pre-index continuous closed medical enrollment, claims or electronic health record (EHR) activity. Individuals with discordant test results on the same day were excluded. Additionally, those who tested SARSCoV-2 NAAT-positive within 60 days following their initial test results (applied only to the index negative group) or were lost to follow-up during those first 60 days were excluded.

For the secondary objective, a cohort of individuals with any record of SARS-CoV-2positive test results were identified. Individuals entered based on their first SARS-CoV-2 antibody or NAAT-positive test result from February 29, 2020, through December 9, 2020. Individuals were required to have $\geq 12$ months of pre-index continuous closed medical enrollment or activity as described above. Individuals with discordant test results on the same day were excluded.

For both objectives, the baseline period was the 12 months prior to the index test date. All available data in this period were used to identify baseline characteristics and comorbid conditions.

Exposure, Outcome and Covariates: 
For the primary objective, individuals entered the cohort upon their first SARS-CoV-2 NAAT or antibody test; those with a positive result were classified as the index-positive group (i.e., established SARS-CoV-2 infection) while individuals whose first NAAT or antibody test result was negative were the index-negative group (i.e., without laboratory evidence of SARSCoV-2 infection). For the secondary objective, the cohort consisted only of individuals who had a SARS-CoV-2 positive test result.

The outcome of interest for both objectives was a SARS-CoV-2 positive NAAT result occurring at $>60$ days after the index test result date. The follow-up time interval began on the 61st day post index date, rather than the patient index date, to avoid misclassifying individuals who experienced prolonged viral RNA shedding in the weeks after their initial infection as having the outcome. ${ }^{4,10,11}$ Individuals were followed until the outcome of interest or the earliest occurrence of inpatient death, outcome of interest, end of available data, end of their medical plan enrollment or end of activity.

\section{Sensitivity analysis}

To demonstrate the robustness of our laboratory confirmed outcome definition, we examined International Classification of Diseases (ICD)-10 diagnosis codes U07.1 or U07.2 in addition to the laboratory test results for outcome ascertainment as ICD codes are commonly used in real-world research to define occurrence of COVID-19 and may affect the outcome rate. $^{12}$

\section{Statistical Analysis:}

Variables included as baseline characteristics and model covariates are defined in the supplement and were reported descriptively (eMethods1 and eMethods2). Continuous variables 
are presented as means (with standard deviation) and/or medians (with interquartile range).

Categorical variables are presented as absolute and relative frequencies. Demographic covariates were assessed on the index date. Regions are defined by the US Census Bureau. ${ }^{13}$ Presence of comorbidities was assessed during the 12-month baseline period prior to the index date, unless specified otherwise in the supplement. For the primary objective, missing data that occurred in covariates or descriptive variables were classified using a missing data indicator.

For the primary objective, propensity score matching, estimated via logistic regression, was used to adjust for potential confounding between index-positive and index-negative individuals on the index date. Individuals were matched by propensity score on a 1:1 basis using a caliper of $1.0 \%$. Variables included in the propensity-score model are defined in the supplement (eMethods 1). Covariate balance post-matching was evaluated using standardized differences with a threshold of $<0.10$ to indicate well-balanced differences. ${ }^{14}$

For the primary objective, we report the crude rate of SARS-CoV-2 infection per 1,000 person-years (PY) and present cumulative incidence curves. We used Cox proportional-hazard regression to estimate the hazard ratios $(\mathrm{HR})$ and $95 \% \mathrm{CI}$ of the primary outcome for indexpositive versus index-negative individuals during follow-up.

For the secondary objective, we estimated the crude rate of reinfection per 1,000 PY in the overall population and by demographic subgroups. Association between individual risk factors and reinfection was explored using a Cox proportional hazard regression model. Characteristics of interest included individual demographics and comorbid conditions. Missing data elements that occurred in characteristics of interest were classified as the most frequently occurring value for categorical variables. We prespecified a 2-tailed alpha of 0.05 to establish 
medRxiv preprint doi: https://doi.org/10.1101/2022.02.25.22271515; this version posted February 26, 2022. The copyright holder for this preprint (which was not certified by peer review) is the author/funder, who has granted medRxiv a license to display the preprint in perpetuity.

All rights reserved. No reuse allowed without permission.

statistical significance. Data were analyzed using the previously validated Aetion Evidence Platform version r4.27.0.20210609 and R version 3.4.2.

\section{Results}

For the primary objective, 27,070,023 individuals met the inclusion criteria, of which 7,501 died and 4,275,540 disenrolled between index and start of follow-up; 22,786,982 individuals started follow-up 61 days post- index date. Of these, 2,023,341 (9\%) were SARSCoV-2 index-positive and 20,763,641 (91\%) were SARS-CoV-2 index-negative. There were similar age and sex distributions between index-positive and index-negative individuals: a mean age of 43 and 45 years with $57 \%$ and $60 \%$ female, respectively. The index-negative population exhibited slightly worse comorbid illness (average Charlson-Quan score of 0.55 versus 0.49 for the index-positive). Median follow-up time was 149 days and 162 days for index-positive and index-negative groups, respectively. Index-positive individuals had fewer NAAT tests during follow-up than index-negative individuals (mean (SD) 0.40 (2.55) vs. 0.78 (3.29) respectively). All index-positive individuals were matched to an index-negative individual in the propensityscore model, with 2,023,341 individuals in each group. Characteristics were well balanced before and after matching (Table 1).

A total of 737,742 cases of infection were observed in the unmatched population over the follow-up period; $8,869(1.2 \%)$ occurred in the index-positive group. The crude rate of reinfection over follow-up was substantially lower in the index-positive group (9.89 per 1,000person year) than in the index-negative group (78.39 per 1,000 PY) (Table 2). The cumulative incidence of reinfection was $0.85 \%$ (95\% CI: $0.82 \%, 0.88 \%)$ among index-positive individuals and for infection the rate was $6.2 \%$ (95\% CI: $6.1 \%, 6.3 \%)$ among index-negative individuals 
over a follow-up of 375 days from the index date (Figure 1). The risk of reinfection was stable over the median 5 months of follow-up and up to one year among index-positive individuals ( $n=1,821,183$ at 4 months, $n=859,824$ at 8 months and $n=147,458$ at 12 months). After adjustment for baseline demographic and comorbid characteristics, the risk of reinfection in the index-positive group was $87 \%$ lower than the risk of infection in the index-negative group $(\mathrm{HR}=$ 0.13, 95\% CI: $(0.13,0.13))$. A propensity-score matched analysis provided a nearly identical estimate of the degree and duration of protection. The adjusted risk of infection over follow-up time was relatively stable $(6-8$ months post-index $(\mathrm{HR}=0.12,95 \% \mathrm{CI}:(0.12,0.13) ; 8-10$ months post-index $(\mathrm{HR}=0.17,95 \% \mathrm{CI}: 0.15,0.18) ; 10-12$ months post-index $(\mathrm{HR}=0.15,95 \% \mathrm{CI}: 0.13$, $0.18)$ ). Stratified by index-test type (antibody only $(n=2,617,139)$, NAAT only $(n=19,857,392)$ or both $(n=312,451)$, the adjusted risk of reinfection was similar to the pooled estimate $(\mathrm{HR}=0.14,95 \% \mathrm{CI}:(0.13,0.15)$ for antibody only; HR=0.13 95\% CI: $(0.13,0.13)$ for NAAT only; HR=0.13, 95\% CI: $(0.08,0.20)$ for both on index $)$. These data suggest that SARS-CoV-2 infection provides substantial protection from reinfection for at least 5 months and up to one year from recovery.

To demonstrate the robustness of laboratory-confirmed COVID defining our outcome, a sensitivity analysis incorporating ICD-10 diagnostic codes to the primary outcome was performed in the primary analysis cohort. The direction of the association was consistent with the primary analysis; however, we estimated only a $27 \%$ reduction (fully-adjusted $\mathrm{HR}=0.73$ (95\% CI: $0.72,0.73)$ ) in risk of reinfection among index-positive individuals versus infection among index-negative individuals, compared to an $87 \%$ reduction in the main analysis.

To test the robustness of the prolonged viral shedding period definition on outcome estimates and to align to other previously published literature, we examined a 90-day exclusion 
period in addition to the primary definition of 60 days. ${ }^{15-17}$ Findings (not shown) were nearly identical to the primary definition results indicating minimal bias in 60 versus 90 -day viral shedding exclusion period definitions.

For the secondary study objective, 3,213,214 individuals met the criteria for the SARSCoV-2-positive cohort, of whom 2,535,887 individuals were not censored due to death, disenrollment, or the end of data prior to beginning follow-up 61 days after their index date. The mean age was 44 years, $58.1 \%$ were female and the average Charlson-Quan score was 0.51 (Table 3). Median follow-up time was 155 days. Characteristics were similar between patients who were reinfected and those who were not.

During follow-up, the crude rate of reinfection was 11.75 (CI: 11.55, 11.96) per 1,000 PY; 12,642 cases over 1,075,563 PY. Individuals $\geq 85$ years of age were more likely to be reinfected compared to those aged 18-29 years. This was particularly true in the Midwest and South regions. Additionally, individuals living in a skilled nursing facility (SNF) or in congregate care settings were 1.5 and 2.8 times as likely to be reinfected compared to those not residing in these settings on the index date, respectively. In the South and Midwest geographies, those in congregate care settings had a 4-times higher risk compared to those not living in congregate care settings. Patients with comorbid immunologic conditions had a $37 \%$ higher risk of being reinfected than those without. The risk of reinfection among other comorbid conditions, such as heart failure, varied by geographic region. Healthcare workers were less than half as likely to be reinfected compared to the general population. (Table 4). These results suggest that immunity to SARS-CoV-2 reinfection may be less durable in elderly patients, those living in congregate setting, and in individuals with impaired immune function. 


\section{Discussion}

Among a cohort of $>22$ million individuals with SARS-CoV-2 laboratory test results, the risk of reinfection in index-positive individuals was $87 \%$ lower compared to risk of infection among index-negative individuals. This association was consistent in unadjusted, fully-adjusted, and among propensity-score matched model estimates. The observed protection against reinfection was durable for at least one year. Factors associated with an increased likelihood of reinfection included older age, comorbid immunological conditions, and living in congregate care setting. Consistent with other studies, healthcare workers were half as likely to be reinfected compared to the general population, which may be associated with lifestyle factors and/or activities to reduce transmission, such as social distancing and use of mask wearing. ${ }^{18-20}$

Our prior work suggested $90 \%$ protection in a real-world cohort of 3.2 million individuals. ${ }^{4}$ In this current analysis, the observed magnitude of the decreased risk of infection is consistent with other limited published estimates that have been obtained with smaller cohorts that mainly examined shorter periods of protection. ${ }^{15,19,21}$ This work adds to our prior findings showing that the real-world use of widely available diagnostics (antibody assays and NAAT) can identify individuals with prior infection and reliably predict long-term risk of reinfection.

Consistent with findings from this study, in a recent US study among over 325,000 patients from a health system spanning two states who were PCR tested for SARS-CoV-2 between March 2020 and September 2021, the duration of long-term protection afforded from primary SARS-CoV-2 infection was up to 13 months. ${ }^{22}$ A population-based study of over 500,000 individuals in Denmark evaluating infection measured by PCR testing during the second COVID-19 surge among patients who were tested in the first COVID-19 surge, suggest duration 
lasting at least 7 months, as no waning immunity was observed when comparing results at 3-6 months vs. $\geq 7$ months. ${ }^{21}$ Further, a meta-analysis conducted in 2021 suggested that immunity from primary SARS-COV-2 infection likely persists through one year. ${ }^{23}$ This present study now extends those observations by examining a much larger, real-world population followed for over a year.

The stable level of protection from reinfection observed in this study through the first year after SARS-CoV-2 infection differs from the duration of protection after two doses of a SARS-CoV-2 mRNA vaccine, which has been reported to decrease after a few months. ${ }^{24}$ This difference may not be surprising, given what is known about duration of protection from other subunit vaccines compared with duration of protection following viral infection ${ }^{25}$, and the much more rapid reported decrease in antibody titer following two doses of a SARS-CoV-2 mRNA vaccine compared with the rate of decrease after viral infection. ${ }^{26}$

Of importance to future studies utilizing real-world evidence and diagnostic codes where more reliable laboratory data aren't readily available as in our study, when ICD-10 diagnostic codes were added to the primary outcome definition, we found a notably lower risk reduction (27\%) for reinfection vs. infection. This suggests the lack of specificity in COVID-19 ICD-10 codes. Other studies have found variable positive predictive value of COVID ICD-10 codes based on care setting (i.e., inpatient or outpatient). ${ }^{27-30}$

The present study identified a large national population using data from medical and pharmacy claims, retail pharmacy data, and electronic medical records. This large size and broad representation across many evaluated attributes allowed better characterization of subgroups. These data are not specifically intended for research purposes; thus, the completeness of medical information is unknown. Additionally, certain risk factors for infection, such as frequency of 
exposure to SARS-CoV-2 are not captured in the RWD. We were, therefore, not able to assess social and behavioral factors that likely influence risk of reinfection, which may be why we observe the same effect estimates in the crude and adjusted models

These data are mainly drawn from a medically insured individuals, except for laboratory or retail pharmacy data coming directly from available clinical laboratory and retail pharmacy sources. As such, these data may not be representative of the medically uninsured individuals, although there is no a priori reason to believe their results would be different. During follow-up, index negative individuals had slightly more follow-up time and NAAT tests than index-positive, which may overestimate the true protective effect observed. Further, false-negative NAAT test results among the index-negative may underestimate the true protective effect observed. ${ }^{31}$. Study data aren't inclusive of time periods of variant circulation (i.e. Delta, Omicron); durability of protection may vary for these and future SARS-CoV-2 variants.

The primary outcome definition inherently required individuals to be observable, and without evidence of positive test results if in the index-negative group, until 61 days following their index date, thereby introducing immortal time bias (i.e. bias in the estimator due to exclusion of time intervals, in this case 60 days post-index). However, this decision was warranted to ensure residual viral shedding wasn't captured during a primary infection, creating a more specific outcome definition. ${ }^{9-11}$

In summary, this large US population-based study demonstrates that SARS-CoV-2 reinfection is uncommon among individuals with laboratory evidence of a previous infection. Protection from SARS-CoV-2 reinfection is stable for up to one year. Reinfection risk was primarily associated with age $85+$ years, comorbid immunologic conditions and living in congregate care settings; healthcare workers demonstrated a decreased reinfection risk. These 
findings suggest that infection induced immunity is durable for variants circulating prior to Delta.

\section{Acknowledgement}

All authors completed the ICMJE uniform disclosure form at: www.icmje.org/coi_disclosure.pdf and declare: Shannon L. Reynolds and Christopher Bush had full access to all the data and take full responsibility for the integrity of the data and the accuracy of the data analysis. Shannon L.

Reynolds, Carly Kabelac, and Christopher Bush are employees of and own stock in Aetion, Inc. Harvey W. Kaufman and William A. Meyer III are employees of and own stock in Quest Diagnostics. Oren Cohon and Steve Anderson are employees of and own stock in Labcorp Drug Development. Steve Anderson has received consulting fees from Luminex. Douglas Lowry has received royalty-related payments from NIH. Kathy Cronin, Sandy Leonard, Valentina Petkov, Norman Sharpless, and Lynne Penberthy report no conflict of interests. The authors would like to acknowledge Wendy Turenne for her support on this engagement and Reyna Klesh for her data expertise support. 


\section{References}

1. Johns Hopkins Coronavirus Resource Center. https://coronavirus.jhu.edu/ (2020).

2. Iwasaki A. What reinfections mean for COVID-19. The Lancet Infectious Diseases. 2020;0(0). doi:10.1016/S1473-3099(20)30783-0

3. Adrielle dos Santos L, Filho PG de G, Silva AMF, et al. Recurrent COVID-19 including evidence of reinfection and enhanced severity in thirty Brazilian healthcare workers. Journal of Infection. Published online February 13, 2021. doi:10.1016/j.jinf.2021.01.020

4. Harvey RA, Rassen JA, Kabelac CA, et al. Association of SARS-CoV-2 Seropositive Antibody Test With Risk of Future Infection. JAMA Intern Med. Published online February 24, 2021. doi:10.1001/jamainternmed.2021.0366

5. Lumley SF, O’Donnell D, Stoesser NE, et al. Antibody Status and Incidence of SARSCoV-2 Infection in Health Care Workers. New England Journal of Medicine. 2021;384(6):533-540. doi:10.1056/NEJMoa2034545

6. Hanrath AT, Payne BAI, Duncan CJA. Prior SARS-CoV-2 infection is associated with protection against symptomatic reinfection. Journal of Infection. 2020;0(0). doi: $10.1016 / j . j i n f .2020 .12 .023$

7. Hall V, Foulkes S, Charlett A, et al. Do Antibody Positive Healthcare Workers Have Lower SARS-CoV-2 Infection Rates than Antibody Negative Healthcare Workers? Large Multi-Centre Prospective Cohort Study (the SIREN Study), England: June to November 2020.; 2021:2021.01.13.21249642. doi:10.1101/2021.01.13.21249642

8. Hall VJ, Foulkes S, Charlett A, et al. SARS-CoV-2 infection rates of antibody-positive compared with antibody-negative health-care workers in England: a large, multicentre, 
medRxiv preprint doi: https://doi.org/10.1101/2022.02.25.22271515; this version posted February 26, 2022. The copyright holder for this preprint (which was not certified by peer review) is the author/funder, who has granted medRxiv a license to display the preprint in perpetuity.

All rights reserved. No reuse allowed without permission.

prospective cohort study (SIREN). Lancet. 2021;397(10283):1459-1469.

doi:10.1016/S0140-6736(21)00675-9

9. Rennert L, McMahan C. Risk of SARS-CoV-2 reinfection in a university student population. Clin Infect Dis. Published online May 16, 2021 :ciab454.

doi: $10.1093 / \mathrm{cid} / \mathrm{ciab} 454$

10. Wajnberg A, Mansour M, Leven E, et al. Humoral response and PCR positivity in patients with COVID-19 in the New York City region, USA: an observational study. The Lancet Microbe. 2020;1(7):e283-e289. doi:10.1016/S2666-5247(20)30120-8

11. Addetia A, Crawford KH, Dingens A, et al. Neutralizing antibodies correlate with protection from SARS-CoV-2 in humans during a fishery vessel outbreak with high attack rate. medRxiv. Published online January 1, 2020:2020.08.13.20173161. doi: $10.1101 / 2020.08 .13 .20173161$

12. Centers for Disease Control and Prevention. ICD - ICD-10-CM - International Classification of Diseases, Tenth Revision, Clinical Modification (cdc.gov). Accessed November 30, 2021.

13. United States Census Bureau. us regdiv.pdf (census.gov) Accessed November 30, 2021.

14. Austin PC. Balance diagnostics for comparing the distribution of baseline covariates between treatment groups in propensity-score matched samples. Stat Med. 2009;28(25):3083-3107.

15. Sheehan MM, Reddy AJ, Rothberg MB. Reinfection Rates among Patients who Previously Tested Positive for COVID-19: a Retrospective Cohort Study. Clin Infect Dis. 2021 Mar 15:ciab234. Accessed October 20, 2021. 
medRxiv preprint doi: https://doi.org/10.1101/2022.02.25.22271515; this version posted February 26, 2022. The copyright holder for this preprint (which was not certified by peer review) is the author/funder, who has granted medRxiv a license to display the preprint in perpetuity.

All rights reserved. No reuse allowed without permission.

16. Vibholm LK, Nielsen SS, Pahus MH, et al. SARS-CoV-2 persistence is associated with antigen-specific CD8 T-cell responses. EBioMedicine. 2021;64:103230. doi:10.1016/j.ebiom.2021.103230

17. Vitale J, Mumoli N, Clerici P, et al. Assessment of SARS-CoV-2 Reinfection 1 Year After Primary Infection in a Population in Lombardy, Italy. JAMA Internal Medicine. 2021;181(10):1407-1408. doi:10.1001/jamainternmed.2021.2959

18. Linsenmeyer K, Charness ME, O’Brien WJ, et al. Vaccination Status and the Detection of SARS-CoV-2 Infection in Health Care Personnel Under Surveillance in Long-term Residential Facilities. JAMA Network Open. 2021;4(11):e2134229. doi:10.1001/jamanetworkopen.2021.34229

19. Krutikov M, Palmer T, Tut G, et al. Incidence of SARS-CoV-2 infection according to baseline antibody status in staff and residents of 100 long-term care facilities (VIVALDI): a prospective cohort study. The Lancet Healthy Longevity. 2021;2(6):e362e370. doi:10.1016/S2666-7568(21)00093-3

20. Sami S, Akinbami LJ, Petersen LR, et al. Prevalence of SARS-CoV-2 Antibodies in First Responders and Public Safety Personnel, New York City, New York, USA, May-July 2020. Emerg Infect Dis. 2021;27(3):796-804. doi:10.3201/eid2703.204340

21. Hansen CH, Michlmayr D, Gubbels SM, Mølbak K, Ethelberg S. Assessment of protection against reinfection with SARS-CoV-2 among 4 million PCR-tested individuals in Denmark in 2020: a population-level observational study. The Lancet 2021;397(10280):1204-12.

22. Kim P, Gordon SM, Sheehan MM, Rothberg MB. Duration of Severe Acute Respiratory Syndrome Coronavirus 2 Natural Immunity and Protection Against the Delta Variant: A 
medRxiv preprint doi: https://doi.org/10.1101/2022.02.25.22271515; this version posted February 26, 2022. The copyright holder for this preprint (which was not certified by peer review) is the author/funder, who has granted medRxiv a license to display the preprint in perpetuity.

All rights reserved. No reuse allowed without permission.

Retrospective Cohort Study. Clinical Infectious Diseases. Published online December 3, 2021:ciab999. doi:10.1093/cid/ciab999

23. Petráš M. Highly Effective Naturally Acquired Protection Against COVID-19 Persists for at Least 1 Year: A Meta-Analysis. Journal of the American Medical Directors Association. 2021;22(11):2263-2265. doi:10.1016/j.jamda.2021.08.042

24. Israel A, Merzon E, Schäffer AA, et al. Elapsed time since BNT162b2 vaccine and risk of SARS-CoV-2 infection: test negative design study. BMJ. 2021;375:e067873. doi:10.1136/bmj-2021-067873

25. Slifka MK, Amanna IJ. Role of Multivalency and Antigenic Threshold in Generating Protective Antibody Responses. Frontiers in Immunology. 2019;10. Accessed January 24, 2022. https://www.frontiersin.org/article/10.3389/fimmu.2019.00956

26. Israel A, Shenhar Y, Green I, et al. Large-Scale Study of Antibody Titer Decay following BNT162b2 mRNA Vaccine or SARS-CoV-2 Infection. Vaccines (Basel). 2021;10(1):64. doi:10.3390/vaccines10010064

27. Bhatt AS, McElrath EE, Claggett BL, et al. Accuracy of ICD-10 Diagnostic Codes to Identify COVID-19 Among Hospitalized Patients. J Gen Intern Med. 2021;36(8):25322535. doi:10.1007/s11606-021-06936-w

28. Redondo-González O, Tenías JM, Arias Á, Lucendo AJ. Validity and Reliability of Administrative Coded Data for the Identification of Hospital-Acquired Infections: An Updated Systematic Review with Meta-Analysis and Meta-Regression Analysis. Health Serv Res. 2018;53(3):1919-1956. doi:10.1111/1475-6773.12691 
medRxiv preprint doi: https://doi.org/10.1101/2022.02.25.22271515; this version posted February 26, 2022. The copyright holder for this preprint (which was not certified by peer review) is the author/funder, who has granted medRxiv a license to display the preprint in perpetuity. All rights reserved. No reuse allowed without permission.

29. Kadri SS, Gundrum J, Warner S, et al. Uptake and Accuracy of the Diagnosis Code for COVID-19 Among US Hospitalizations. JAMA. 2020;324(24):2553-2554.

doi:10.1001/jama.2020.20323

30. Lynch KE, Viernes B, Gatsby E, et al. Positive Predictive Value of COVID-19 ICD-10 Diagnosis Codes Across Calendar Time and Clinical Setting. Clin Epidemiol. 2021;13:1011-1018. doi:10.2147/CLEP.S335621

31. Kucirka LM, Lauer SA, Laeyendecker O, Boon D, Lessler J. Variation in False-Negative Rate of Reverse Transcriptase Polymerase Chain Reaction-Based SARS-CoV-2 Tests by Time Since Exposure. Ann Intern Med. 2020 Aug 18;173(4):262-267. doi: 10.7326/M201495. Epub 2020 May 13. PMID: 32422057; PMCID: PMC7240870. 
Table 1. Demographics and baseline comorbidities in the 365 days prior to first SARS-CoV-2 test among a SARS-CoV-2-tested cohort and among a postpropensity score match population identified between February 29th, 2020 through December 9th, 2020

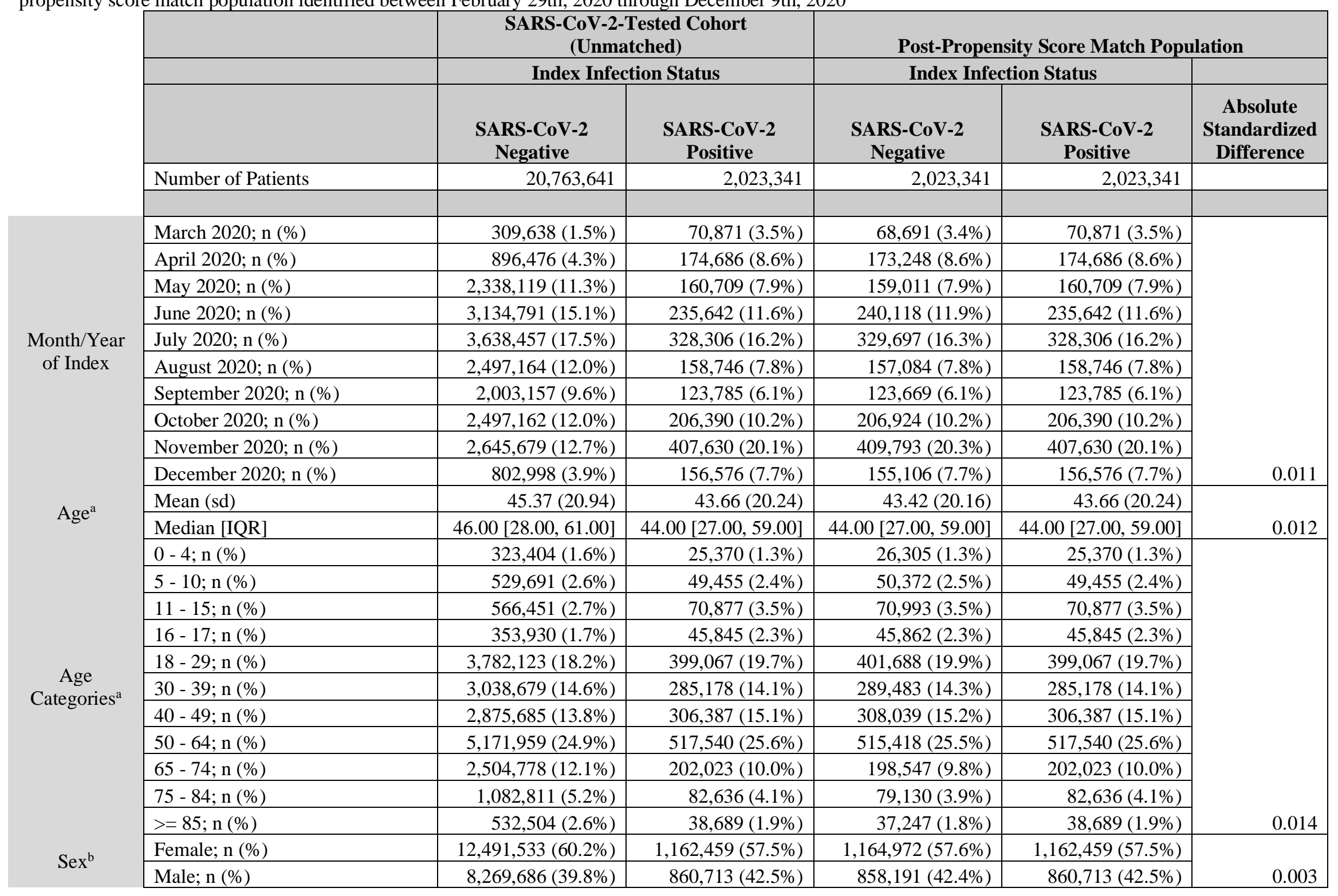


Table 1. Demographics and baseline comorbidities in the 365 days prior to first SARS-CoV-2 test among a SARS-CoV-2-tested cohort and among a post-propensity score match population identified between February 29th, 2020 through December 9th, 2020 (continued)

\begin{tabular}{|c|c|c|c|c|c|c|}
\hline & & \multicolumn{2}{|c|}{$\begin{array}{c}\begin{array}{c}\text { SARS-CoV-2-Tested Cohort } \\
\text { (Unmatched) }\end{array} \\
\text { Index Infection Status } \\
\end{array}$} & \multicolumn{3}{|c|}{ Post-Propensity Score Match Population } \\
\hline & & $\begin{array}{l}\text { SARS-CoV-2 } \\
\text { Negative }\end{array}$ & $\begin{array}{l}\text { SARS-CoV-2 } \\
\text { Positive }\end{array}$ & $\begin{array}{c}\text { SARS-CoV-2 } \\
\text { Negative }\end{array}$ & $\begin{array}{l}\text { SARS-CoV-2 } \\
\text { Positive }\end{array}$ & $\begin{array}{c}\text { Absolute } \\
\text { Standardized } \\
\text { Difference }\end{array}$ \\
\hline \multirow[b]{2}{*}{ Insurance } & $\begin{array}{l}\text { Other or Unknown Insurance; } \mathrm{n} \\
(\%)\end{array}$ & $13,351,117(64.3 \%)$ & $1,185,231(58.6 \%)$ & $1,190,371(58.8 \%)$ & $1,185,231(58.6 \%)$ & \multirow{2}{*}{0.025} \\
\hline & Commercial; n (\%) & $4,924,029(23.7 \%)$ & $521,501(25.8 \%)$ & $524,664(25.9 \%)$ & $521,501(25.8 \%)$ & \\
\hline \multirow{5}{*}{$\begin{array}{l}\text { Geographic } \\
\text { Region }\end{array}$} & Northeast; $\mathrm{n}(\%)$ & $5,765,112(27.8 \%)$ & $511,139(25.3 \%)$ & $490,536(24.2 \%)$ & $511,139(25.3 \%)$ & \multirow[b]{5}{*}{0.024} \\
\hline & Midwest; n (\%) & $3,210,459(15.5 \%)$ & $368,391(18.2 \%)$ & $374,743(18.5 \%)$ & $368,391(18.2 \%)$ & \\
\hline & South; n (\%) & $7,533,647(36.3 \%)$ & $758,303(37.5 \%)$ & $768,518(38.0 \%)$ & $758,303(37.5 \%)$ & \\
\hline & West; $\mathrm{n}(\%)$ & 4,030,702 (19.4\%) & $361,860(17.9 \%)$ & $365,669(18.1 \%)$ & $361,860(17.9 \%)$ & \\
\hline & Other/Missing; n (\%) & $223,721(1.1 \%)$ & $23,648(1.2 \%)$ & $23,875(1.2 \%)$ & $23,648(1.2 \%)$ & \\
\hline $\begin{array}{l}\text { Residence or } \\
\text { Site of Care }\end{array}$ & Congregate Care; n (\%) & $18,365(0.1 \%)$ & $1,779(0.1 \%)$ & $1,588(0.1 \%)$ & $1,779(0.1 \%)$ & 0.003 \\
\hline $\begin{array}{l}\text { Healthcare } \\
\text { Worker } \\
\text { Index Test } \\
\text { Type }\end{array}$ & Antibody Test; n (\%) & $2,699,093(13.0 \%)$ & $230,497(11.4 \%)$ & $225,405(11.1 \%)$ & $230,497(11.4 \%)$ & 0.008 \\
\hline \multirow{3}{*}{$\begin{array}{l}\text { Charlson- } \\
\text { Quan Score, } \\
365 \text { Days }\end{array}$} & Mean (sd) & $0.55(1.32)$ & $0.49(1.23)$ & $0.45(1.14)$ & $0.49(1.23)$ & \multirow[b]{2}{*}{0.037} \\
\hline & Median [IQR] & $0.00[0.00,0.00]$ & $0.00[0.00,0.00]$ & $0.00[0.00,0.00]$ & $0.00[0.00,0.00]$ & \\
\hline & $\begin{array}{l}\text { Data Unavailable in Pre-index; } n \\
(\%)\end{array}$ & $2,776,487(13.4 \%)$ & $306,165(15 . \%)$ & $272,690(13.5 \%)$ & $306,165(15 . \%)$ & 0.047 \\
\hline \multirow{6}{*}{$\begin{array}{c}\text { Additional } \\
\text { Comorbidities }\end{array}$} & $\begin{array}{l}\text { Acute and Unspecified Renal } \\
\text { Failure; } \mathrm{n}(\%)\end{array}$ & $283,901(1.4 \%)$ & $24,592(1.2 \%)$ & $18,996(0.9 \%)$ & $24,592(1.2 \%)$ & 0.027 \\
\hline & Asthma; n (\%) & $1,170,702(5.6 \%)$ & $102,339(5.1 \%)$ & $96,900(4.8 \%)$ & $102,339(5.1 \%)$ & 0.012 \\
\hline & $\begin{array}{l}\text { Chronic Obstructive Pulmonary } \\
\text { Disease; } \mathrm{n}(\%)\end{array}$ & $688,608(3.3 \%)$ & $43,714(2.2 \%)$ & $37,728(1.9 \%)$ & $43,714(2.2 \%)$ & 0.021 \\
\hline & Coronary Heart Disease; n (\%) & $752,595(3.6 \%)$ & $61,019(3.0 \%)$ & $53,579(2.6 \%)$ & $61,019(3.0 \%)$ & 0.022 \\
\hline & Hypertension; n (\%) & $4,036,841(19.4 \%)$ & $388,738(19.2 \%)$ & $373,436(18.5 \%)$ & $388,738(19.2 \%)$ & 0.019 \\
\hline & Immunity Disorders; $\mathrm{n}(\%)$ & $109,911(0.5 \%)$ & $7,697(0.4 \%)$ & $6,097(0.3 \%)$ & $7,697(0.4 \%)$ & 0.014 \\
\hline
\end{tabular}


Table 1. Demographics and baseline comorbidities in the 365 days prior to first SARS-CoV-2 test among a SARS-CoV-2-tested cohort and among a post-propensity score match population identified between February 29th, 2020 through December 9th, 2020 (continued)

\begin{tabular}{|c|c|c|c|c|c|c|}
\hline & & \multicolumn{2}{|c|}{$\begin{array}{c}\begin{array}{c}\text { SARS-CoV-2-Tested Cohort } \\
\text { (Unmatched) }\end{array} \\
\text { Index Infection Status } \\
\end{array}$} & \multicolumn{3}{|c|}{ Post-Propensity Score Match Population } \\
\hline & & $\begin{array}{c}\text { SARS-CoV-2 } \\
\text { Negative }\end{array}$ & $\begin{array}{l}\text { SARS-CoV-2 } \\
\text { Positive }\end{array}$ & $\begin{array}{c}\text { SARS-CoV-2 } \\
\text { Negative }\end{array}$ & $\begin{array}{l}\text { SARS-CoV-2 } \\
\text { Positive }\end{array}$ & $\begin{array}{c}\text { Absolute } \\
\text { Standardized } \\
\text { Difference }\end{array}$ \\
\hline \multirow{4}{*}{$\begin{array}{l}\text { Additional } \\
\text { Comorbidities }\end{array}$} & Ischemic Heart Disease ; $\mathrm{n}(\%)$ & $889,768(4.3 \%)$ & $73,185(3.6 \%)$ & $63,154(3.1 \%)$ & $73,185(3.6 \%)$ & 0.027 \\
\hline & Metabolic Syndrome; n (\%) & $526,644(2.5 \%)$ & $59,284(2.9 \%)$ & $55,236(2.7 \%)$ & $59,284(2.9 \%)$ & 0.012 \\
\hline & Pneumonia; n (\%) & $399,919(1.9 \%)$ & $49,613(2.5 \%)$ & $40,147(2.0 \%)$ & $49,613(2.5 \%)$ & 0.032 \\
\hline & Underweight; n (\%) & $110,507(0.5 \%)$ & $8,995(0.4 \%)$ & $9,169(0.5 \%)$ & $8,995(0.4 \%)$ & 0.001 \\
\hline \multirow{3}{*}{ Weight } & Normal weight; n (\%) & $1,498,821(7.2 \%)$ & $118,912(5.9 \%)$ & $117,160(5.8 \%)$ & $118,912(5.9 \%)$ & 0.004 \\
\hline & Overweight; n (\%) & $1,931,157(9.3 \%)$ & $184,817(9.1 \%)$ & $180,956(8.9 \%)$ & $184,817(9.1 \%)$ & 0.007 \\
\hline & Obesity; n (\%) & $2,991,072(14.4 \%)$ & $330,400(16.3 \%)$ & $325,109(16.1 \%)$ & $330,400(16.3 \%)$ & 0.007 \\
\hline
\end{tabular}

${ }^{a}$ Among the SARS-CoV-2-Tested Cohort, age was missing for 1,626 index negative and 274 index positive individuals. Among the post-propensity score match population, age was missing for 257 index negative and 274 index positive individuals.

${ }^{b}$ Among the SARS-CoV-2-Tested Cohort, sex was missing/unknown for 2,422 index negative and 169 index positive individuals. Among the post-propensity score match population, sex was missing/unknown for 178 index negative and 169 index positive individuals. 
Table 2. Rate of SARS-CoV-2 positive diagnostic tests in follow-up (April 30th, 2020 through April 30th, 2021) stratified by index SARS-CoV-2 infection status with rate ratio and hazard ratio estimates among SARS-CoV-2 positive individuals vs. SARS CoV-2 negative individuals

\begin{tabular}{|l|r|r|r|r|}
\cline { 2 - 5 } \multicolumn{1}{c|}{} & \multicolumn{2}{c|}{$\begin{array}{c}\text { SARS-CoV-2-Tested Cohort } \\
\text { (Unmatched) }\end{array}$} & $\begin{array}{c}\text { Post-Propensity Score Match } \\
\text { Population }\end{array}$ \\
\cline { 2 - 5 } \multicolumn{1}{l|}{ Parameter } & \multicolumn{2}{|c|}{ Index Infection Status } & \multicolumn{2}{c|}{ Index Infection Status } \\
\hline Number of Patients & $\begin{array}{c}\text { SARS-CoV-2 } \\
\text { Negative }\end{array}$ & $\begin{array}{c}\text { SARS-CoV-2 } \\
\text { Positive }\end{array}$ & $\begin{array}{c}\text { SARS-CoV- } \\
\text { 2 Negative }\end{array}$ & $\begin{array}{c}\text { SARS-CoV-2 } \\
\text { Positive }\end{array}$ \\
\hline Number of Person-Years & $20,763,641$ & $2,023,341$ & $2,023,341$ & $2,023,341$ \\
\hline $\begin{array}{l}\text { Number of SARS-CoV-2 Positive Diagnostic Tests in } \\
\text { Follow-up }\end{array}$ & $9,298,000$ & 897,023 & 885,825 & 897,023 \\
\hline $\begin{array}{l}\text { Rate of SARS-CoV-2 Positive Diagnostic Tests in } \\
\text { Follow-up per 1,000 Person-Years }\end{array}$ & 728,872 & & & \\
\hline Rate Ratio (vs. referent; 95\% CI) & 78.39 & 6,869 & & 8,869 \\
\hline Adjusted Hazard Ratio $\mathbf{1}$ (vs. referent; 95\% CI) & Referent & $0.13(0.12,0.13)$ & Referent & $0.13(0.13,0.13)$ \\
\hline
\end{tabular}

${ }^{a}$ The following variables were adjusted for in the fully-adjusted model that was run on the unmatched population and included as covariates in calculating the propensity score for each individual:

Month/Year of Index, Age, Gender, Insurance Category, U.S. Region, Congregate Care, SNF, Healthcare Worker, Diagnostic Test on Index, Antibody Test on Index, Charlson-Quan Score Over Prior 365 Days, Pneumonia, Asthma, Chronic Obstructive Pulmonary Disease, Immunity Disorders, Acute and Unspecified Renal Failure, Ischemic Heart Disease, Hypertension, Coronary Heart Disease, Metabolic Syndrome, Vitamin D Deficiency, Underweight, Normal Weight, Overweight, Obesity 
Table 3. Demographics and baseline comorbidities in the 365 days prior to first SARS-CoV-2 positive test among a SARS-CoV-2-positive cohort identified between February 29th, 2020 through December 9th, 2020

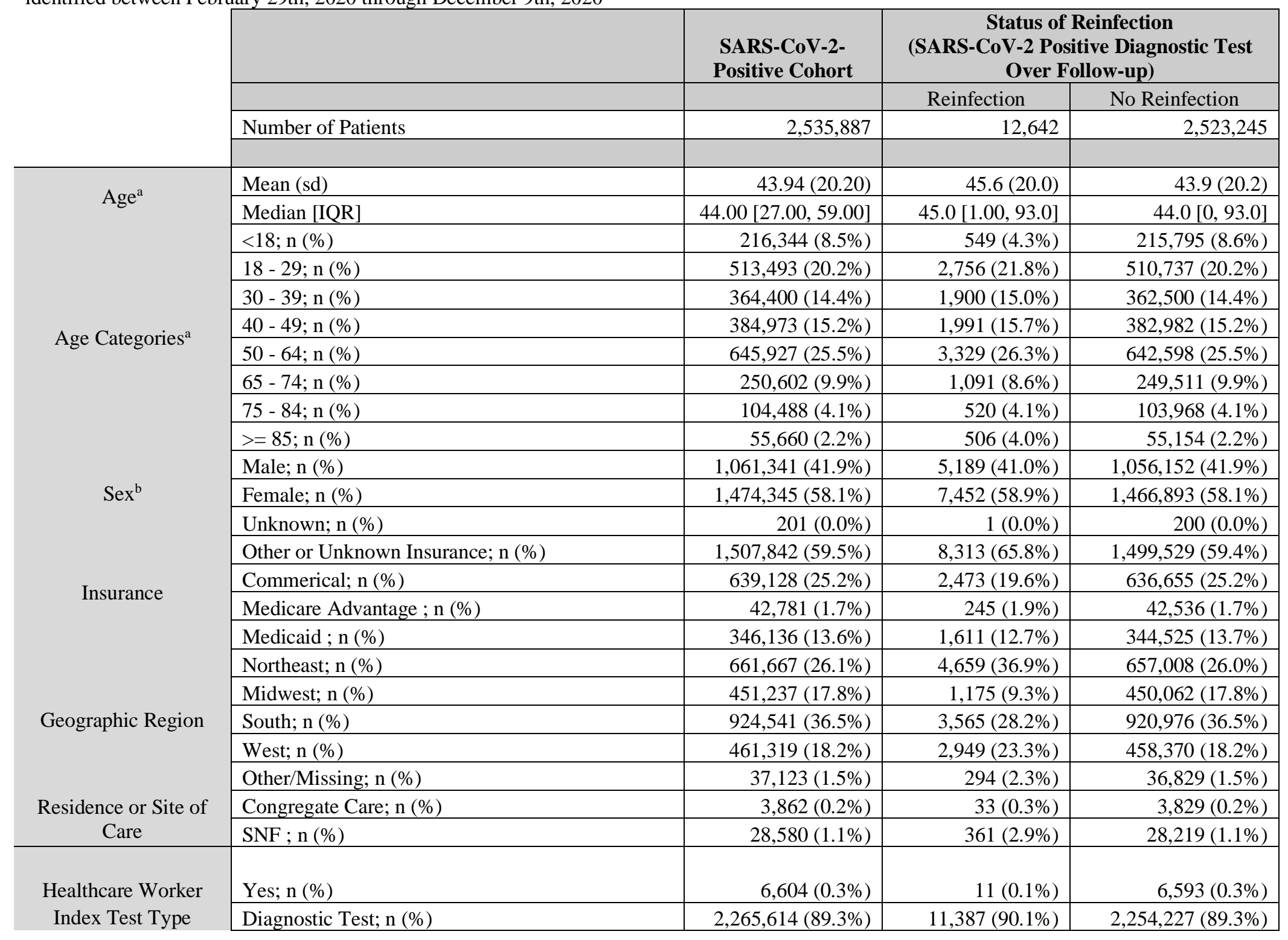


Table 3. Demographics and baseline comorbidities in the 365 days prior to first SARS-CoV-2 positive test among a SARS-CoV-2-positive cohort identified between February 29th, 2020 through December 9th, 2020 (continued)

\begin{tabular}{|c|c|c|c|c|}
\hline & & \multirow[t]{2}{*}{$\begin{array}{l}\text { SARS-CoV-2- } \\
\text { Positive Cohort }\end{array}$} & \multicolumn{2}{|c|}{$\begin{array}{c}\text { Status of Reinfection } \\
\text { (SARS-CoV-2 Positive Diagnostic Test } \\
\text { Over Follow-up) }\end{array}$} \\
\hline & & & Reinfection & No Reinfection \\
\hline & Antibody Test; $\mathrm{n}(\%)$ & $322,065(12.7 \%)$ & $1,655(13.1 \%)$ & $320,410(12.7 \%)$ \\
\hline \multirow{3}{*}{$\begin{array}{c}\text { Hospitalization } \\
\text { Assessed } 10 \text { Days Pre- } \\
\text { index Through Start of } \\
\text { Follow-up }\end{array}$} & No Hospitalization ; n (\%) & $2,492,337(98.3 \%)$ & $11,991(94.9 \%)$ & $2,423,634(96.1 \%)$ \\
\hline & $\begin{array}{l}\text { Hospitalization With COVID-related } \\
\text { Diagnosis/Symptoms; } \mathrm{n}(\%)\end{array}$ & $35,432(1.4 \%)$ & $508(4.0 \%)$ & $77,422(3.1 \%)$ \\
\hline & $\begin{array}{l}\text { ICU and Hospitalization With COVID-related } \\
\text { Diagnosis/Symptoms; } \mathrm{n}(\%)\end{array}$ & $8,118(0.3 \%)$ & $143(1.1 \%)$ & $22,189(0.9 \%)$ \\
\hline \multirow{3}{*}{$\begin{array}{l}\text { Charlson-Quan Score, } \\
365 \text { Days }\end{array}$} & Mean (sd) & $0.51(1.27)$ & $0.713(1.57)$ & $0.510(1.27)$ \\
\hline & Median [IQR] & $0.00[0.00,0.00]$ & $0[0,15.0]$ & $0[0,21.0]$ \\
\hline & Data Unavailable in Pre-index; n $(\%)$ & $379,244(15.0 \%)$ & $2,091(16.5 \%)$ & $377,153(14.9 \%)$ \\
\hline \multirow{11}{*}{$\begin{array}{c}\text { Additional } \\
\text { Comorbidities }\end{array}$} & Acute and Unspecified Renal Failure; $\mathrm{n}(\%)$ & $34,078(1.3 \%)$ & $302(2.4 \%)$ & $33,776(1.3 \%)$ \\
\hline & Asthma; n (\%) & $131,875(5.2 \%)$ & $781(6.2 \%)$ & $131,094(5.2 \%)$ \\
\hline & Chronic Obstructive Pulmonary Disease; n (\%) & $203,451(8.0 \%)$ & $1,262(10.0 \%)$ & $202,189(8.0 \%)$ \\
\hline & Coronary Heart Disease; $\mathrm{n}(\%)$ & $80,403(3.2 \%)$ & $542(4.3 \%)$ & $79,861(3.2 \%)$ \\
\hline & Hypertension; n (\%) & $494,021(19.5 \%)$ & $2,819(22.3 \%)$ & $491,202(19.5 \%)$ \\
\hline & Immunity Disorders; $\mathrm{n}(\%)$ & $10,015(0.4 \%)$ & $82(0.6 \%)$ & $9,933(0.4 \%)$ \\
\hline & Ischemic Heart Disease ; n (\%) & $96,057(3.8 \%)$ & $646(5.1 \%)$ & $95,411(3.8 \%)$ \\
\hline & Metabolic Syndrome; n (\%) & $75,362(3.0 \%)$ & $475(3.8 \%)$ & $74,887(3.0 \%)$ \\
\hline & Pneumonia; $\mathrm{n}(\%)$ & $66,874(2.6 \%)$ & $466(3.7 \%)$ & $66,408(2.6 \%)$ \\
\hline & Vitamin D Deficiency ; n (\%) & $184,215(7.3 \%)$ & $1,034(8.2 \%)$ & $183,181(7.3 \%)$ \\
\hline & Comorbidity Data Unavailable in Pre-index; n (\%) & $303,847(12.0 \%)$ & $1,626(12.9 \%)$ & $302,221(12.0 \%)$ \\
\hline \multirow{4}{*}{ Weight } & Underweight ; n (\%) & $10,672(0.4 \%)$ & $39(0.3 \%)$ & $10,633(0.4 \%)$ \\
\hline & Normal weight; $\mathrm{n}(\%)$ & $150,979(6.0 \%)$ & $798(6.3 \%)$ & $150,181(6.0 \%)$ \\
\hline & Overweight; n (\%) & $231,568(9.1 \%)$ & $1,297(10.3 \%)$ & $230,271(9.1 \%)$ \\
\hline & Obesity; n (\%) & $413,571(16.3 \%)$ & $2,350(18.6 \%)$ & $411,221(16.3 \%)$ \\
\hline
\end{tabular}

${ }^{a}$ Among the SARS-CoV-2-Positive Cohort, age is missing for 278 individuals. Individuals with missing age were reassigned to the most frequently occurring group - the 50 - 64 year old category.

${ }^{\mathrm{b}}$ Among the SARS-CoV-2-Positive Cohort, sex is missing for 16 individuals. Individuals with missing sex were reassigned to the most frequently occurring group - female. 
Table 4. Measured association of demographic and clinical factors with re-infection (SARS-CoV-2 positive diagnostic test during follow-up (April 30th, 2020 through April 30th, 2021)) among individuals with history of SARS-CoV-2 infection identified between February 29th, 2020 through December 9th, 2020

\begin{tabular}{|c|c|c|c|c|c|c|}
\hline & & $\begin{array}{l}\text { SARS-CoV-2- } \\
\text { Positive Cohort }\end{array}$ & Northeast & Midwest & South & West \\
\hline & & $\begin{array}{l}\text { Multivariate } \\
\text { Estimates }\end{array}$ & $\begin{array}{c}\text { Multivariate } \\
\text { Estimates }\end{array}$ & $\begin{array}{c}\text { Multivariate } \\
\text { Estimates }\end{array}$ & $\begin{array}{l}\text { Multivariate } \\
\text { Estimates }\end{array}$ & $\begin{array}{l}\text { Multivariate } \\
\text { Estimates }\end{array}$ \\
\hline & & $\begin{array}{l}\text { Hazard Ratio } \\
(95 \% \text { CI })\end{array}$ & $\begin{array}{c}\text { Hazard Ratio } \\
(95 \% \mathrm{CI})\end{array}$ & $\begin{array}{c}\text { Hazard Ratio } \\
(95 \% \text { CI })\end{array}$ & $\begin{array}{c}\text { Hazard Ratio } \\
(95 \% \text { CI })\end{array}$ & $\begin{array}{c}\text { Hazard Ratio } \\
(95 \% \text { CI })\end{array}$ \\
\hline \multirow{7}{*}{$\begin{array}{c}\text { Categorical Age }{ }^{\mathrm{a}} \text { (vs. } \\
18-29)\end{array}$} & Aged $<18$ & $0.50(0.45,0.54)$ & $0.44(0.38,0.53)$ & $0.68(0.51,0.92)$ & $0.49(0.42,0.58)$ & $0.53(0.45,0.64)$ \\
\hline & Aged 30-39 & $0.94(0.89,1.00)$ & $0.89(0.80,0.98)$ & $1.00(0.82,1.21)$ & $0.89(0.79,1.00)$ & $0.99(0.88,1.11)$ \\
\hline & Aged 40-49 & $0.91(0.86,0.96)$ & $0.89(0.81,0.98)$ & $0.91(0.75,1.11)$ & $0.90(0.81,1.01)$ & $0.93(0.83,1.05)$ \\
\hline & Aged 50-64 & $0.88(0.83,0.93)$ & $0.82(0.75,0.90)$ & $0.99(0.84,1.18)$ & $0.88(0.79,0.97)$ & $0.91(0.82,1.02)$ \\
\hline & Aged 65-74 & $0.75(0.69,0.80)$ & $0.63(0.56,0.72)$ & $0.90(0.71,1.15)$ & $0.84(0.74,0.96)$ & $0.72(0.61,0.85)$ \\
\hline & Aged 75-84 & $0.82(0.74,0.91)$ & $0.73(0.62,0.87)$ & $1.07(0.79,1.46)$ & $0.84(0.70,1.01)$ & $0.88(0.71,1.08)$ \\
\hline & Aged 85+ & $1.29(1.16,1.43)$ & $1.04(0.87,1.24)$ & $1.77(1.29,2.44)$ & $1.59(1.32,1.93)$ & $1.12(0.87,1.45)$ \\
\hline \multirow{2}{*}{$\operatorname{Sex}^{\mathrm{b}}$ (vs. Female) } & Male & $1.01(0.97,1.04)$ & $0.98(0.92,1.04)$ & $0.90(0.80,1.02)$ & $1.01(0.94,1.08)$ & $0.99(0.92,1.07)$ \\
\hline & Unknown & $1.86(0.26,13.20)$ & $0.00(0.00, \infty)$ & $0.00(0.00,0.00)$ & $7.24(1.02,51.4)$ & $0.00(0.00, \infty)$ \\
\hline \multirow{2}{*}{$\begin{array}{l}\text { Residence or Site of } \\
\text { Care }\end{array}$} & Congregate Care & $2.80(1.98,3.97)$ & $2.18(1.28,3.71)$ & $2.00(0.87,4.62)$ & $4.11(1.83,9.23)$ & $4.74(1.75,12.83)$ \\
\hline & SNF & $1.53(1.35,1.72)$ & $1.69(1.39,2.03)$ & $1.56(1.08,2.25)$ & $1.61(1.28,2.04)$ & $1.20(0.90,1.58)$ \\
\hline \multirow{3}{*}{$\begin{array}{l}\text { Healthcare Worker } \\
\text { (vs. No) } \\
\text { Hospitalization } \\
\text { Assessed } 10 \text { Days Pre- } \\
\text { index Through Start of } \\
\text { Follow-up (vs. No } \\
\text { Hospitalization) }\end{array}$} & Yes & $0.48(0.27,0.88)$ & $0.51(0.19,1.37)$ & $0.91(0.33,2.51)$ & $0.21(0.03,1.53)$ & $0.27(0.04,1.94)$ \\
\hline & $\begin{array}{l}\text { Hospitalization With COVID- } \\
\text { 19-Related Diagnosis/Symptoms }\end{array}$ & $1.00(0.91,1.09)$ & $0.99(0.84,1.18)$ & $1.03(0.77,1.39)$ & $0.90(0.76,1.07)$ & $1.17(0.99,1.39)$ \\
\hline & $\begin{array}{l}\text { ICU and Hospitalization With } \\
\text { COVID-19-Related } \\
\text { Diagnosis/Symptoms }\end{array}$ & $0.91(0.77,1.08)$ & $0.82(0.57,1.16)$ & $0.58(0.27,1.23)$ & $0.76(0.54,1.05)$ & $1.06(0.83,1.37)$ \\
\hline \multirow{6}{*}{ Comorbid Conditions } & Charlson Deyo Score & $1.04(1.00,1.07)$ & $1.01(0.96,1.06)$ & $1.00(0.87,1.15)$ & $1.08(1.02,1.14)$ & $1.01(0.94,1.09)$ \\
\hline & $\begin{array}{l}\text { Acute and Unspecified Renal } \\
\text { Failure }\end{array}$ & $1.18(1.03,1.35)$ & $1.33(1.06,1.65)$ & $0.68(0.42,1.10)$ & $1.06(0.83,1.36)$ & $1.38(1.07,1.78)$ \\
\hline & Asthma & $1.03(0.91,1.15)$ & $0.99(0.82,1.21)$ & $0.86(0.61,1.23)$ & $0.95(0.77,1.17)$ & $1.21(0.94,1.57)$ \\
\hline & $\begin{array}{l}\text { Chronic Obstructive Pulmonary } \\
\text { Disease }\end{array}$ & $1.02(0.92,1.13)$ & $1.05(0.88,1.25)$ & $1.27(0.93,1.74)$ & $1.09(0.92,1.31)$ & $0.87(0.69,1.10)$ \\
\hline & Congestive Heart Failure & $1.11(0.99,1.24)$ & $1.09(0.90,1.31)$ & $1.50(1.05,2.14)$ & $1.05(0.86,1.29)$ & $1.11(0.87,1.43)$ \\
\hline & Coronary Heart Disease & $0.97(0.79,1.20)$ & $0.90(0.65,1.25)$ & $0.64(0.33,1.24)$ & $1.00(0.69,1.44)$ & $1.50(0.87,2.57)$ \\
\hline
\end{tabular}


Table 4. Measured association of demographic and clinical factors with re-infection (SARS-CoV-2 positive diagnostic test during follow-up (April 30 th, 2020 through April 30th, 2021)) among individuals with history of SARS-CoV-2 infection identified between February 29th, 2020 through December 9th, 2020 (continued)

\begin{tabular}{|c|c|c|c|c|c|c|}
\hline & & $\begin{array}{c}\text { SARS-CoV-2- } \\
\text { Positive Cohort }\end{array}$ & Northeast & Midwest & South & West \\
\hline & & $\begin{array}{l}\text { Multivariate } \\
\text { Estimates }\end{array}$ & $\begin{array}{l}\text { Multivariate } \\
\text { Estimates }\end{array}$ & $\begin{array}{c}\text { Multivariate } \\
\text { Estimates }\end{array}$ & $\begin{array}{c}\text { Multivariate } \\
\text { Estimates }\end{array}$ & $\begin{array}{c}\text { Multivariate } \\
\text { Estimates }\end{array}$ \\
\hline & & $\begin{array}{l}\text { Hazard Ratio } \\
\text { (95\% CI) }\end{array}$ & $\begin{array}{l}\text { Hazard Ratio } \\
(95 \% \text { CI })\end{array}$ & $\begin{array}{l}\text { Hazard Ratio } \\
(95 \% \text { CI })\end{array}$ & $\begin{array}{c}\text { Hazard Ratio } \\
\text { (95\% CI) }\end{array}$ & $\begin{array}{l}\text { Hazard Ratio } \\
\text { (95\% CI) }\end{array}$ \\
\hline \multirow{12}{*}{ Comorbid Conditions } & Diabetes Without Complications & $1.03(0.96,1.11)$ & $1.08(0.96,1.21)$ & $1.09(0.84,1.42)$ & $0.99(0.87,1.13)$ & $0.95(0.81,1.11)$ \\
\hline & Diabetes With Complications & $0.99(0.89,1.10)$ & $0.87(0.73,1.04)$ & $1.10(0.76,1.60)$ & $0.91(0.75,1.11)$ & $1.24(1.00,1.54)$ \\
\hline & History of Malignancy & $1.06(0.94,1.21)$ & $1.04(0.85,1.28)$ & $0.71(0.42,1.20)$ & $1.06(0.84,1.34)$ & $1.37(1.05,1.79)$ \\
\hline & History of Metastatic Solid Tumor & $0.98(0.70,1.36)$ & $1.41(0.85,2.32)$ & $1.02(0.27,3.92)$ & $0.70(0.37,1.33)$ & $0.83(0.41,1.66)$ \\
\hline & Hypertension & $0.88(0.83,0.93)$ & $0.86(0.79,0.94)$ & $0.92(0.77,1.10)$ & $0.95(0.86,1.05)$ & $0.96(0.85,1.08)$ \\
\hline & Immunity Disorders & $1.35(1.08,1.68)$ & $1.32(0.93,1.88)$ & $1.27(0.60,2.69)$ & $1.43(0.96,2.12)$ & $1.40(0.87,2.24)$ \\
\hline & Ischemic Heart Disease & $1.02(0.84,1.24)$ & $1.03(0.75,1.39)$ & $1.47(0.80,2.71)$ & $1.08(0.77,1.53)$ & $0.74(0.44,1.25)$ \\
\hline & Myocardial Infarction & $0.99(0.84,1.18)$ & $1.02(0.76,1.38)$ & $1.10(0.64,1.90)$ & $0.90(0.65,1.24)$ & $0.93(0.66,1.33)$ \\
\hline & Obesity & $1.05(1.00,1.10)$ & $1.05(0.97,1.14)$ & $0.96(0.82,1.13)$ & $0.99(0.90,1.09)$ & $1.15(1.05,1.26)$ \\
\hline & Peripheral Vascular Disease & $1.11(1.00,1.22)$ & $1.19(1.02,1.39)$ & $1.02(0.71,1.48)$ & $1.03(0.86,1.24)$ & $1.09(0.87,1.37)$ \\
\hline & Renal Disease & $0.96(0.85,1.09)$ & $1.03(0.84,1.28)$ & $1.12(0.72,1.73)$ & $0.86(0.70,1.07)$ & $0.96(0.74,1.24)$ \\
\hline & Rheumatic Disease & $1.07(0.92,1.23)$ & $0.97(0.76,1.23)$ & $1.18(0.73,1.92)$ & $1.23(0.96,1.57)$ & $0.98(0.71,1.33)$ \\
\hline \multirow{10}{*}{$\begin{array}{l}\text { Month of Index (vs. } \\
\text { July 2020) }\end{array}$} & Stroke & $1.03(0.92,1.15)$ & $1.09(0.92,1.29)$ & $0.93(0.62,1.40)$ & $0.97(0.79,1.18)$ & $1.07(0.83,1.38)$ \\
\hline & March 2020 & $1.15(1.05,1.26)$ & $0.78(0.68,0.89)$ & $0.62(0.39,0.99)$ & $1.46(1.18,1.79)$ & $0.95(0.71,1.27)$ \\
\hline & April 2020 & $1.29(1.21,1.37)$ & $0.82(0.73,0.92)$ & $1.11(0.88,1.41)$ & $1.94(1.70,2.22)$ & $1.21(1.02,1.44)$ \\
\hline & May 2020 & $1.12(1.05,1.19)$ & $0.73(0.65,0.82)$ & $0.79(0.63,1.01)$ & $1.62(1.42,1.85)$ & $1.04(0.88,1.21)$ \\
\hline & June 2020 & $1.02(0.96,1.08)$ & $0.77(0.67,0.89)$ & $0.95(0.75,1.20)$ & $1.06(0.95,1.17)$ & $1.08(0.97,1.20)$ \\
\hline & August 2020 & $1.15(1.07,1.24)$ & $1.08(0.92,1.27)$ & $0.86(0.69,1.07)$ & $1.15(1.03,1.29)$ & $1.24(1.09,1.42)$ \\
\hline & September 2020 & $1.18(1.09,1.28)$ & $1.16(0.98,1.37)$ & $0.76(0.60,0.96)$ & $1.20(1.05,1.38)$ & $1.26(1.08,1.47)$ \\
\hline & October 2020 & $0.94(0.87,1.01)$ & $1.13(0.97,1.32)$ & $0.51(0.41,0.64)$ & $0.97(0.84,1.11)$ & $0.91(0.78,1.07)$ \\
\hline & November 2020 & $0.76(0.70,0.81)$ & $0.97(0.85,1.12)$ & $0.31(0.25,0.38)$ & $0.81(0.71,0.92)$ & $0.72(0.64,0.83)$ \\
\hline & December 2020 & $0.77(0.69,0.85)$ & $0.93(0.78,1.12)$ & $0.31(0.22,0.43)$ & $0.71(0.57,0.88)$ & $0.65(0.53,0.78)$ \\
\hline
\end{tabular}

${ }^{a}$ Among the SARS-CoV-2-Positive Cohort, age is missing for 278 individuals. Individuals with missing age were reassigned to the most frequently occurring group the 50 - 64 year old category.

${ }^{\mathrm{b}}$ Among the SARS-CoV-2-Positive Cohort, sex is missing for 16 individuals. Individuals with missing sex were reassigned to the most frequently occurring group female. 
${ }^{c}$ Regions were defined as the following: Northeast:\{Connecticut, Maine, Massachusetts, New Hampshire, Rhode Island, Vermont, New Jersey, New York, Pennsylvania\}, Midwest: \{ Indiana, Illinois, Michigan, Ohio, Wisconsin, Iowa, Kansas, Minnesota, Missouri, Nebraska, North Dakota, South Dakota\}, South: \{Delaware, District of Columbia, Florida, Maryland, North Carolina, South Carolina, Virginia, West Virginia, Alabama, Kentucky, Mississippi, Tennessee, Arkansas, Lousiana, Oklahoma, Texas, Georgia,\}, West: \{Arizona, Colorado, Idaho, New Mexico, Montana, Utah, Nevada, Wyoming, Alaska, California, Hawaii, Oregon,

Washington 
medRxiv preprint doi: https://doi.org/10.1101/2022.02.25.22271515; this version posted February 26, 2022. The copyright holder for this preprint (which was not certified by peer review) is the author/funder, who has granted medRxiv a license to display the preprint in perpetuity. All rights reserved. No reuse allowed without permission.

Figure 1. Cumulative incidence of SARS-CoV-2 infection from April 30th, 2020 through April 30th, 2021 among SARS-CoV-2 index positive vs SARS-CoV-2 index negative individuals. There were 71,921 individuals who indexed negative but had a subsequent positive test result within the following 60 days. Of the 27,070,023 index positive and negative individuals, within the first 60 days from index date, 7,501 died in an inpatient setting and 4,275,540 were disenrolled or had no additional claims or EHR activity resulting in 22,786,982 who started follow-up on day 61.

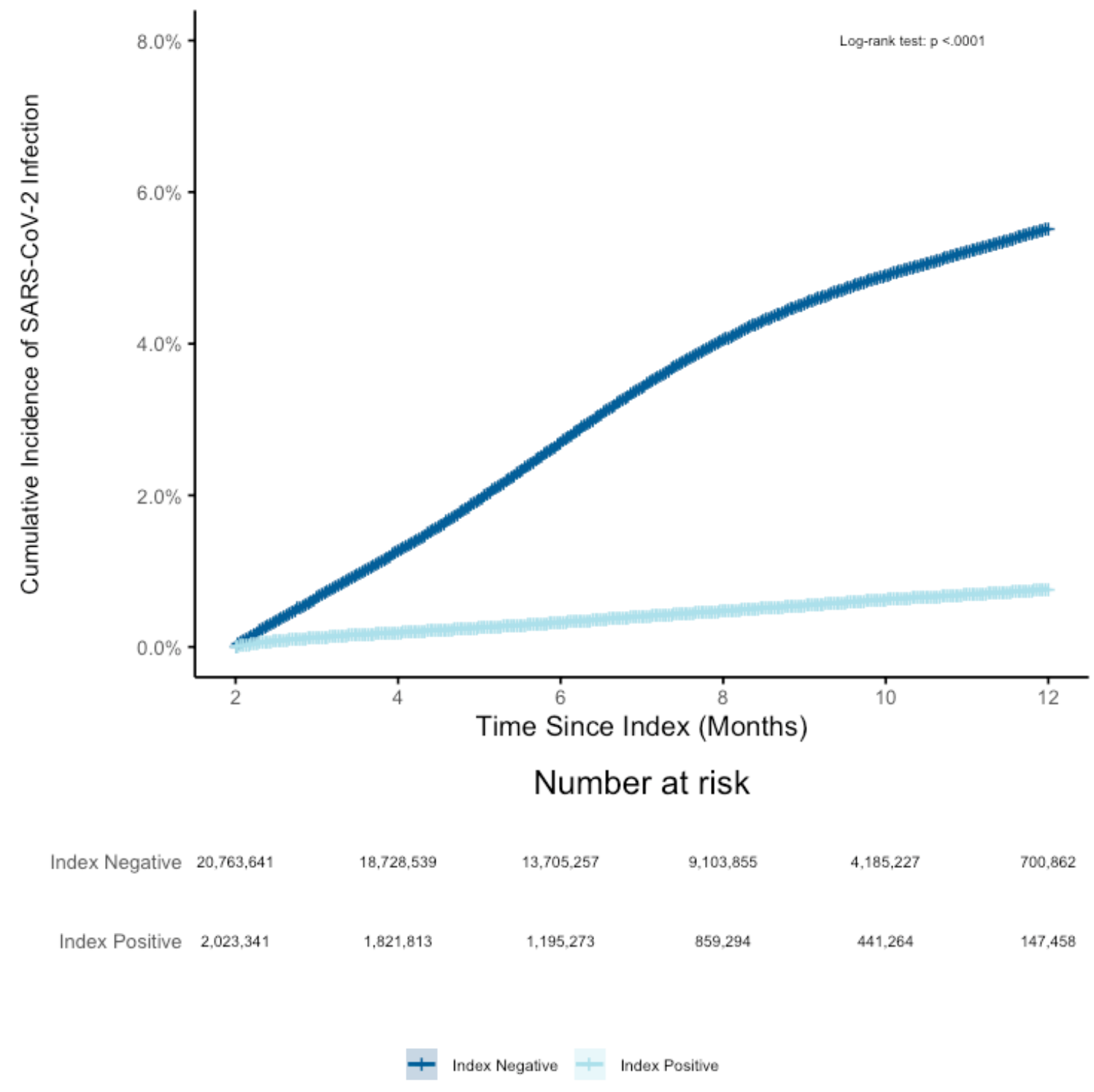

